\title{
Hallazgos en OCT de segmento anterior en lacteocrumenasia
}

\section{Anterior segment-OCT findings in lacteocrumenasia}

Ignacio García-Basterra ${ }^{1 *}$, José Díaz-Bernal' y José Mora-Castilla²

${ }^{1}$ Servicio de Oftalmología, Hospital Universitario Virgen de la Victoria; ${ }^{2}$ Clínica Oftalmológica Antonio Moreno. Málaga, España

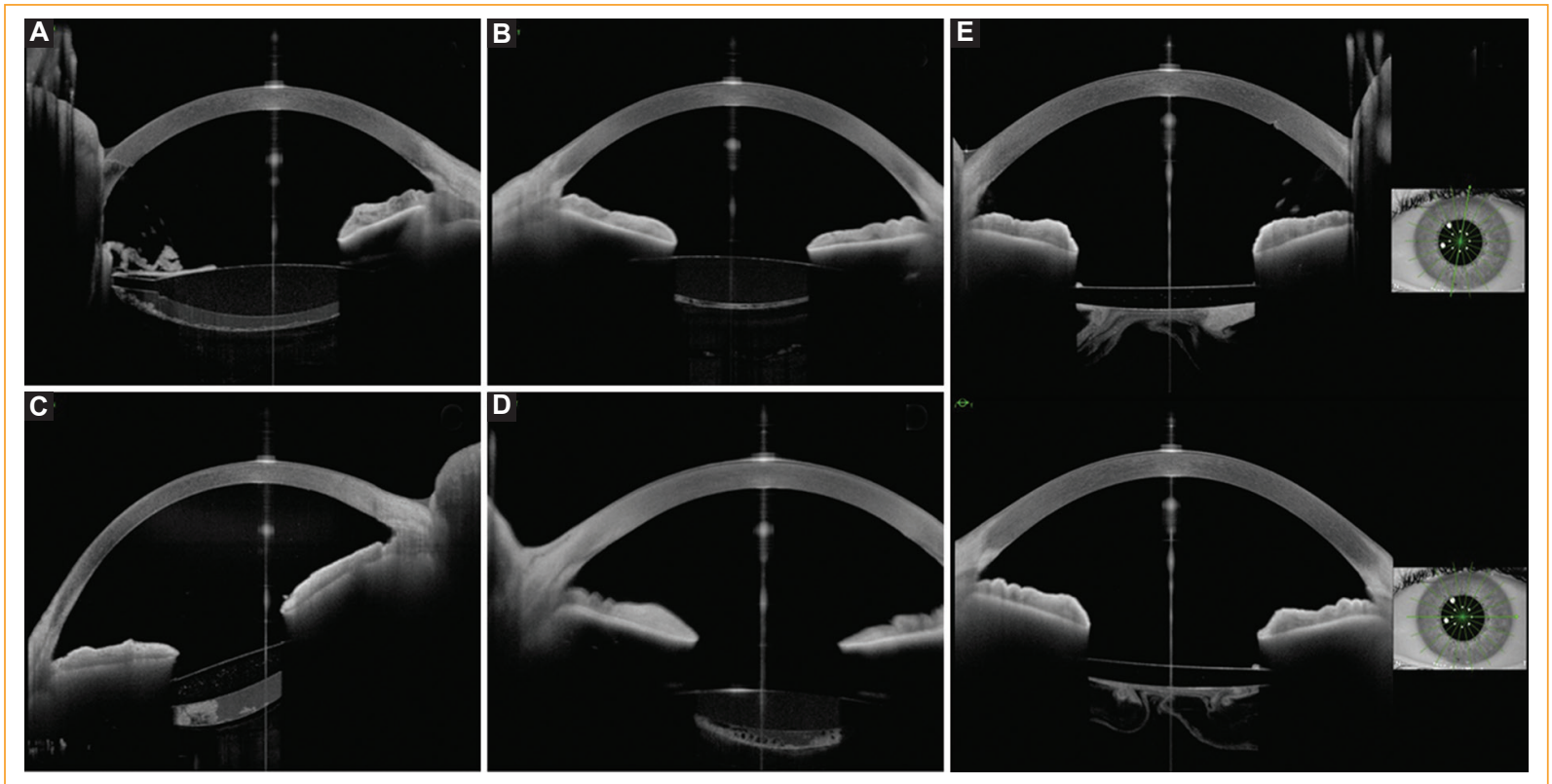

Figura 1. Imágenes de tomografía de coherencia óptica de segmento anterior (OCT-SA) de cinco casos distintos de lacteocrumenasia. A, B, C y D: Se observan distintas presentaciones de lacteocrumenasia, con diferentes grosores y patrones de opacificación. D: Se identifica un patrón pseudoquístico de la opacidad en la parte más posterior del saco. E: Representa el aspecto de un caso de lacteocrumenasia segundos después de la rotura de cápsula posterior con láser YAG.

Mostramos las imágenes de cinco casos de lacteocrumenasia que se presentaron como déficit de agudeza visual varios meses después de la cirugía de catarata (Fig. 1). La lacteocrumenasia es el acúmulo de material aséptico de aspecto lechoso entre la cara posterior de la lente intracapsular y la cápsula posterior ${ }^{1}$. Su presentación clínica habitual es de una disminución de visión con imagen de opacidad de la

\section{Correspondencia:}

*Ignacio García-Basterra.

Hospital Virgen de la Victoria

Campus Teatinos, s/n

Fecha de recepción: 12-05-2020

C.P. 29010, Málaga, España

E-mail: ignaciobas@ hotmail.com
Fecha de aceptación: 30-06-2020

DOI: 10.24875/RMO.M20000133
Disponible en internet: 09-11-2020 Rev Mex Oftalmol. 2020;94(6):289-290

www.rmo.com.mx 0187-4519/C 2020 Sociedad Mexicana de Oftalmología. Publicado por Permanyer. Este es un artículo open access bajo la licencia CC BY-NC-ND (http://creativecommons.org/licenses/by-nc-nd/4.0/). 
cápsula posterior en la lámpara de hendidura. El estudio con tomografía de coherencia óptica de segmento anterior (OCT-SA) ayuda de forma objetiva y no invasiva a la identificación de esta entidad.

\section{Conflicto de intereses}

Los autores declaran no tener ningún conflicto de interés ni haber recibido financiación para la realización de este trabajo.

\section{Responsabilidades éticas}

Protección de personas y animales: Los autores declaran que los procedimientos seguidos se conformaron a las normas éticas del comité de experimentación humana responsable y de acuerdo con la Asociación Médica Mundial y la Declaración de Helsinki.

Confidencialidad de los datos: Los autores declaran que han seguido los protocolos de su centro de trabajo sobre la publicación de datos de pacientes.

Derecho a la privacidad y consentimiento informado: Los autores han obtenido el consentimiento informado de los pacientes y/o sujetos referidos en el artículo. Este documento obra en poder del autor de correspondencia.

\section{Bibliografía}

1. Kim, HK, Shin JP. Capsular block syndrome after cataract surgery: clinical analysis and classification. J Cataract Refract Surg. 200834(3):357-63. 